\title{
Sao Paulo Metropolitan Transformations: Innovation or Reproduction
}

\author{
Daniela M. Eigenheer ${ }^{1}$, Nadia Somekh ${ }^{2}$ \\ ${ }^{1}$ Departament of Urban Planner, University of Sao Paulo FAU-USP, São Paulo, Brazil \\ ${ }^{2}$ Departament of Urban Planner, University Presbiteriana Mackenzie UPM, So Paulo, Brazil
}

Email address:

deigenhe@gmail.com (D. M. Eigenheer), nadiasom@terra.com.br (N. Somekh)

\section{To cite this article:}

Daniela M. Eigenheer, Nadia Somekh. Sao Paulo Metropolitan Transformations: Innovation or Reproduction. Urban and Regional Planning. Vol. 4, No. 2, 2019, pp. 48-52. doi: 10.11648/j.urp.20190402.11

Received: January 10, 2019; Accepted: April 1, 2019; Published: May 29, 2019

\begin{abstract}
On the understanding that urbanization trends incorporate spatial changes of the economy, the research analyzes post-2000 new dynamics of urban sprawl, linked to the advanced economies that are changing the land use patterns along the northwest vector of Sao Paulo state capital. The vector structured by the Anhanguera / Bandeirantes highway system links the metropolitan region of Sao Paulo with the metropolitan region of Campinas. It is considered the major economic development axis of the country. Located in this area, the research focuses on small cities, due to their recent formation, as well as, the greater intensity of tertiary sector occupations linked to the advanced economies in their urban land. From the regional point of view, it is observed the strengthening of these new centers and of a larger territory that extends beyond the metropolitan scale. This article intend to understand the logic of this process, which is related to new productive structures and produce a new organization of metropolitan territories, that overlap on the old "Metropolitan Area", reproducing dynamics of urban sprawl , at the same time establishing a new morphological configuration of the territory.
\end{abstract}

Keywords: Urban Sprawl, Infrastructure, Metropolitan Territories

\section{Introduction}

It starts from the hypothesis that the trends of urbanization incorporate spatial transformations of the economy and that the production of the capitalist space is based on relations of production, exchange and consumption. This space is transformed, according to the different stages of the process of capitalist accumulation.

Technological advances and infrastructures change the relations of production, exchange and consumption, at the same time, they are strategically planned to support and enlarge constantly the process of capitalist accumulation, supporting and changing the space, and producing new territorial scales.

Currently, the infrastructure network allowed the accumulation of capital to free itself of physical barriers, moving instantly and without regulation. Exist a transnational and financial order of production that configure new spaces without limits, therefore, the circulation of capital must require rules and obstacles so that their accumulation does not destroy the physical space through the time [6].
From this, it is observed that economic and social transformations, necessary for the maintenance of the accumulation of the capitalist economy, have generated new forms of social organization that have produced new configurations and territorial dimensions.

Expressions as Territories of Dispersion [12] Reterritorialization and Operational Landscape [3] citiesregion [11], bring new approaches to refer to the new scales that the intensification of dispersion dynamics has been producing. Accordind to the above, the objective of this article is to point out the logic and the local and regional impact of new dynamics of urban sprawl that has taken place from the first decade of the XXI century in the urban tissue of territories located in vector northwestern in its $90 \mathrm{~km}$ strech between the metropolitan regions of Sao Paulo and Campinas, currently supported by the AnhangueraBandeirantes highway system.

The research will focus on this axis constituted of a system of highways, due to the greater intensity of their occupations linked to capitalism's economy advances, as well as, an intense process of urban transformation that has produced 
morphological changes in this axis and significant regional impacts.

The empirical study focuses in small cities (Cajamar, Louveira, Valinhos and Vinhedo), located in this important national production vector, currently responsible for the

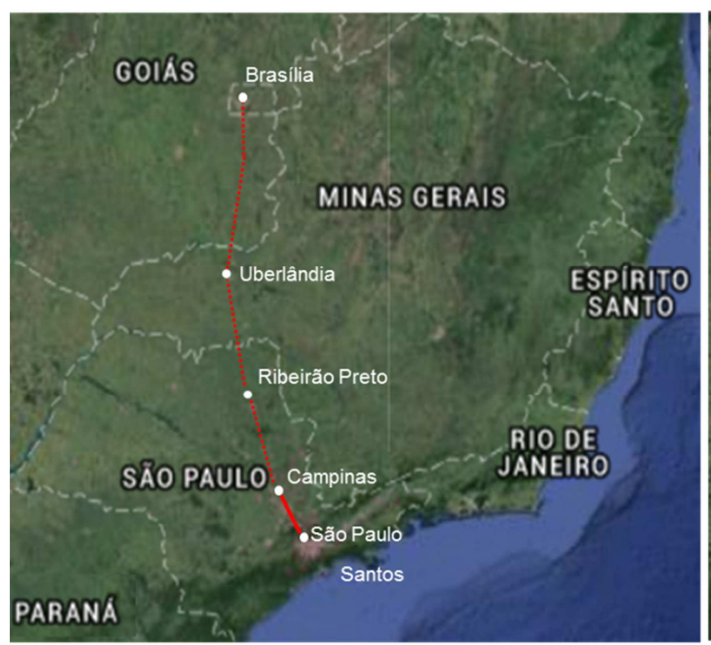

second largest GDP of the state. Besides connecting the two richest metropolitan areas of the state, Sao Paulo (20.5 million people) and Campinas ( 3 million people), it is the main connection between the largest metropolis of the country, Sao Paulo, and the federal capita, Brasilia.

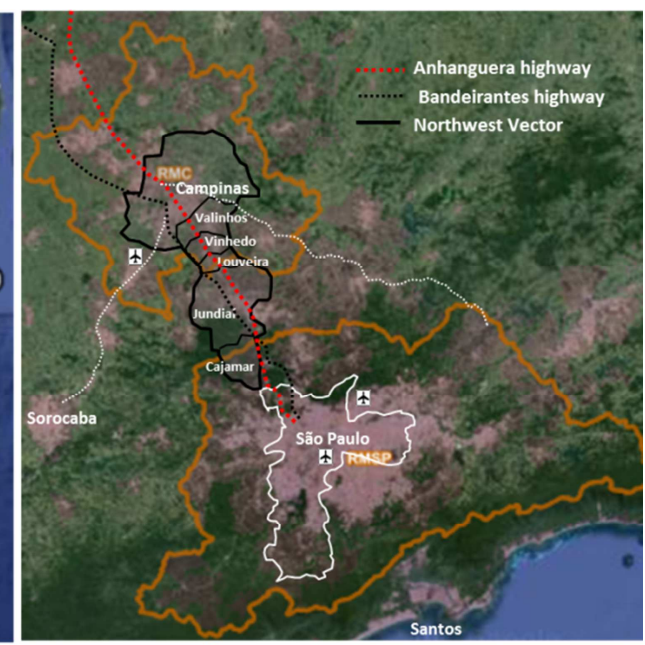

Source: Made from the image of http://www.emplasageo.sp.gov.br, acessed on 15/jun/2016.

Figure 1. Northwest Vector: state and macro-metropolis location.

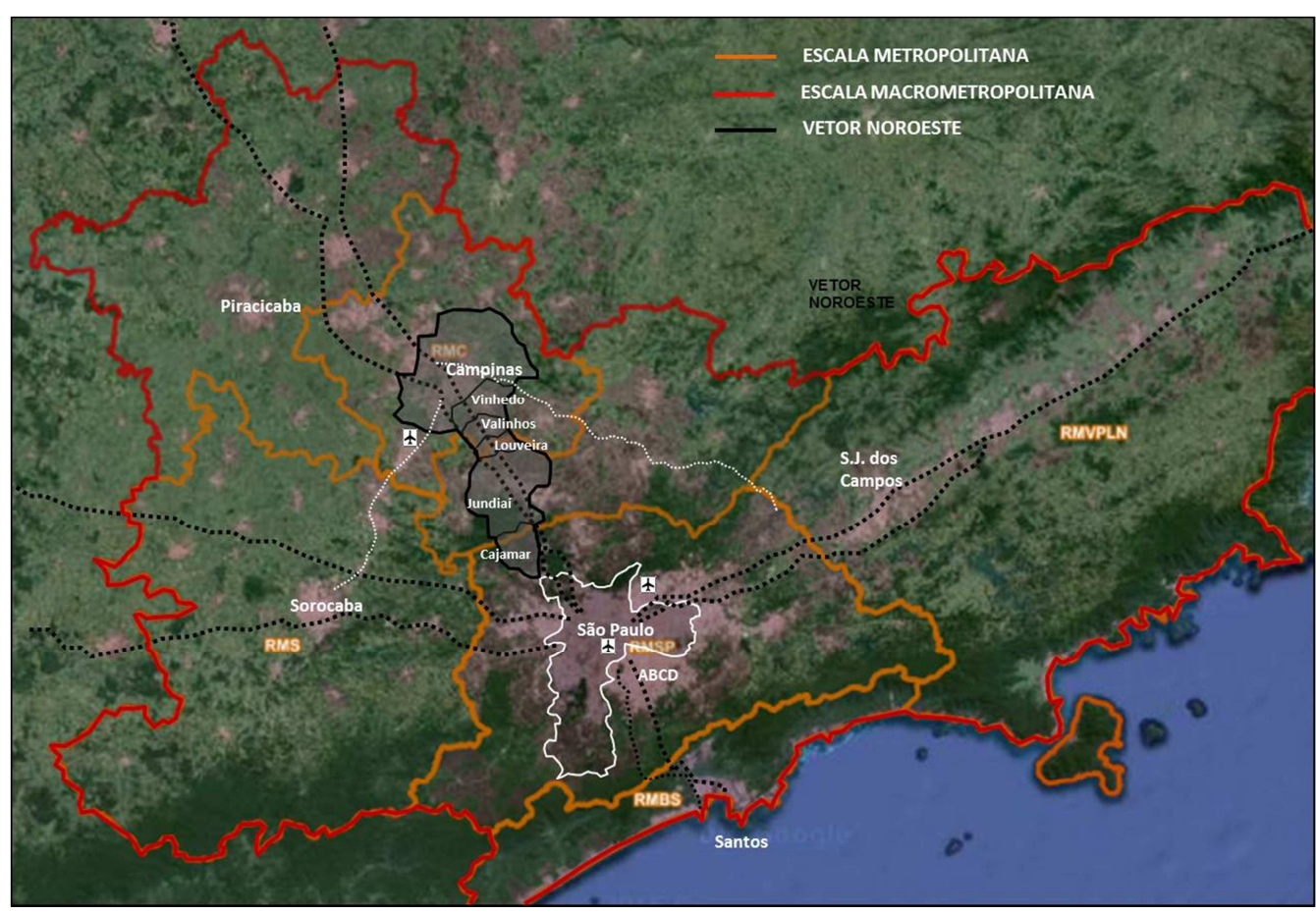

Source: Made from the image of http://www.emplasageo.sp.gov.br, accessed on 15/06/2016

Figure 2. Northewest vector located in São Paulo Macro-Metropolis.

According to the image the small cities (about 70 thousand people each) belong to different metropolitan areas. Valinhos and Vinhedo (6th GDP per capita of the state) belong to the metropolitan area of Campinas. Louveira (1st GDP per capita of the state), belongs to the urban agglomeration of Jundiaí. Cajamar is inserted in the metropolitan area of Sao Paulo.

About the infrastructure assets in this territory, It is important to emphasize the important international airport
(Viracopos), located in the metropolitan area of Campinas being enlarged and renovated to relief Guarulhos International Airport.

Besides the main infrastructure based on the AnhangueraBandeirantes highway system, there are two secondary highways leaving Campinas. One of them goes to the metropolitan area of Sorocaba passing by Viracopos Airport. The other one links the interior of the state with the north 
coast, besides it is conecting an important oil refinery located at the Campinas metropolitan area with the coast area where it is located the Pré-salt, an area of oil deposits found beneath a deep layer of rock salt.

About the productive and social facilities structure, there are two technopolos and one of the country's most important universities (Unicamp) located in Campinas city. In Jundiaí there is one technopole all small cities have an industrial area located beside Anhanguera Highway.

All of these transport and production infrastructure have been enabling the urban and economic development of the northwest vector, the main axis of the Sao Paulo macrometropolis ( 31 million people). This process has strengthened a macro territory that extends the metropolitan dimension, requiring public policies with a new scope.

\section{Metropolitan Evolution}

The analysis of the northwest vector should keep in mind that each time a region is analyzed, it should be understood that there was a specific economic development related to a specific technical or infrastructure, and this space is always in a transformation process [8].

In other words, It discusses the evolution process of a historical axis that since the eighteenth century, has as main function the transport of wealth between prosperous interior, the capital and the port of Santos. The various cycles of economic development of this vector (Gold century XVIII; Coffee-century XIX;. Industrialization-1940/50; Production decentralization- 1970; Globalization and Economic Restructuring -1990), were made possible by different infrastructures, at the same time, they allowed that new urban scales were settled in that territory [5].

The railways were of great importance for the structuring of this territory, but they were disabled throughout the twentieth century and gradually replaced by a modern road network. In the second half of the twentieth century, the highway systems become essential to industrialization and to the establishment of Sao Paulo metropolitan area. In 1948, Anhanguera Highway was opened in northwest vector. It was completed in 1978 by the Bandeirantes highway, which allowed the development and establishment of Campinas metropolitan area.

The intensification of socio-economic relations between these two metropolitan areas, was possible by the continuous modernization of its highway infrastructures. In the 1990s, this process allowed the enlargement of Sao Paulo extended metropolitan area, called Sao Paulo Macro-Metropolis. This region has as the main development axis, the vector northwest, structured by the Anhanguera-Bandeirantes highway system.

From 1990, the Anhanguera / Bandeirantes highways system was transformed in a major productive and regional corridor of mobility, with heavy industrial and urban development.

Through SEADE data (State System of Data Analysis), it is observed in the first decade of this century, the changing of the second largest state GDP (Gross Domestic Product), located until 2011 in Sao Paulo metropolitan area (ABCD area), to the Sao Paulo northwest vector (between Sao Paulo and Campinas city), inserted into the macro-metropolis scale, bringing significant urban impacts, from the local and regional point of view [4].

The dynamics of urban sprawl begin in this vector, from the 1970s, in the context of productive decentralization of Sao Paulo metropolis towards to the interior and other states, after that, in the context of economy restructuring (1990) [8].

From the new century, the productive restructuring process supported by globalization, by advanced tertiary sector, and by modern infrastructures was intensified, increasing theurban sprawl dynamics. In addition to advanced industries, people start to live far from major metropolitan centers, attracting also the global trade (global supply chains) and the advanced tertiary sector to the small cities.

However, after 2000, the intensification of these dynamics, due to the advances of the capitalist economy has been producing new patterns of urban fabric, which start to present different morphological features from those presented by the dynamics of urban sprawl [4].

It is emphasized that this process ais present throughout the whole northwest vector, although in small cities (Cajamar, Louveira, Vinhedo e Valinhos) with strategic location and recent urbanization process, they are more obvious than in metropolitan areas already established (Sao Paulo and Campinas), where these occupations mix with others that have occurred in other socio-economic contexts.

The strong performance of the real estate market and the modernization of tertiary sector (technopoles, industrial parks, logistics and gated condominium, malls, supermarkets, schools, universities, and a large global supply chains,), are examples of new land uses coming from the advanced capitalist economy.

It means, as bigger the insertion of an urban agglomeration in the modern economy, as bigger will be the role of their advanced services and the restructuring of its urban space. Similarly, the less advanced economies will maintain a more traditional urban structure, without major changes in its urban dynamics [1].

From the urban land point of view, the intense occupation of this vector for these new patterns of land use ( linked to modern economy) has promoted the filling of empty urban spaces that still exist from the productive deconcentration and urban sprawl processes, resulting in the gradual loss of one of the main physical characteristic of the urban sprawl process that is the discontinuous urban fabric.

Considering the observations made in some small cities), located at the northwest vector ( Valinhos, Vinhedo, Louveira e Cajamar), it seems that the urban sprawl dynamics should be considered as a stage of a larger process that has been leading to a more advanced urbanization shape [4].

These new shapes have an urban morphology characterized by territorial continuity, but it does not originate from the central core but from the assemblage of scattered areas, due to their occupation for uses linked to 
advanced process of economic restructuring, Although it still remain the same territorial fragmentation conditions or lack of relationship between local environments, occurred in the spatial organization of scattered territories .

It is observed that the infrastructure evolution in this vector, allows new land use related to advances in modern economy and strengthens new urban centers, which gradually become more and more autonomous and less subjected to the urban agglomerations or metropolises already established. This means the shift from traditionally mono-centric cities built around central core towards to a more polycentric urban region.

Considering this macro territory extended, continuous and fragmented, but spatially integrate, the question that arises is how to manage the new logic of spaces where people relate in multiple dimensions that go beyond the municipal and metropolitan administrative boundaries established, at the same time, which is not related to the physical space that it occupies or with its local surroundings [2].

There is a lack of metropolitan and regional public policies that may have a comprehensive and integrated impact on this scattered territory, which is not inserted in the municipal and metropolitan boundaries established. It is important to understand the logical of this transformation in order to produce public policies able of management and control this important structuring productive axis of Sao Paulo macrometropolis.

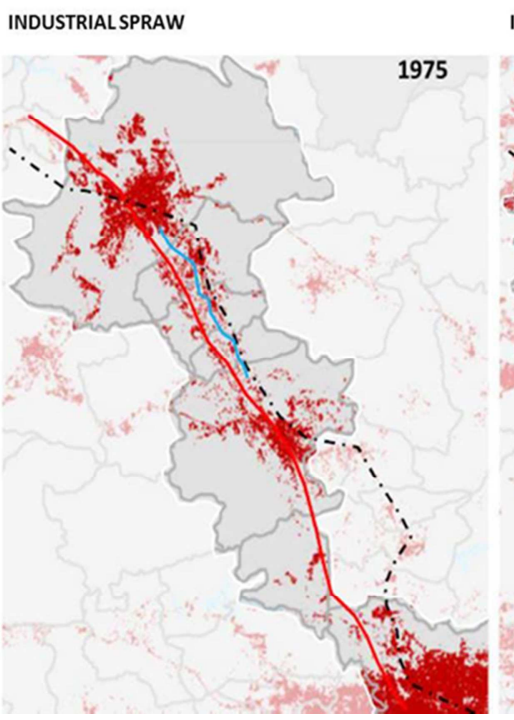

INDUSTRIALANDURBAN SPRAWL

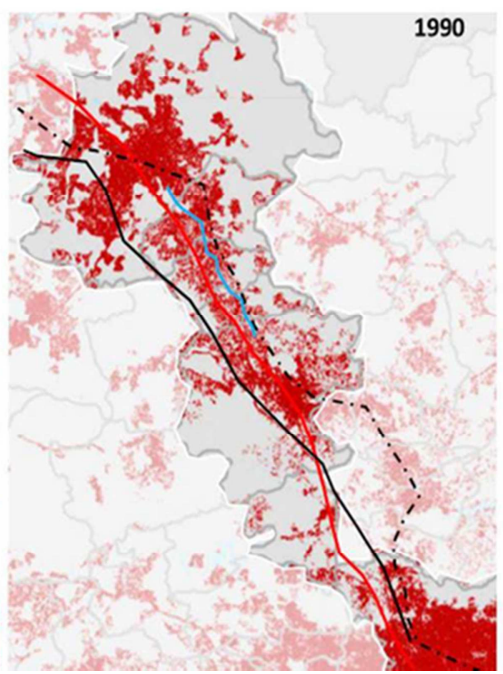

INDUSTRIAL, URBAN AND SERVICE SPRAWL

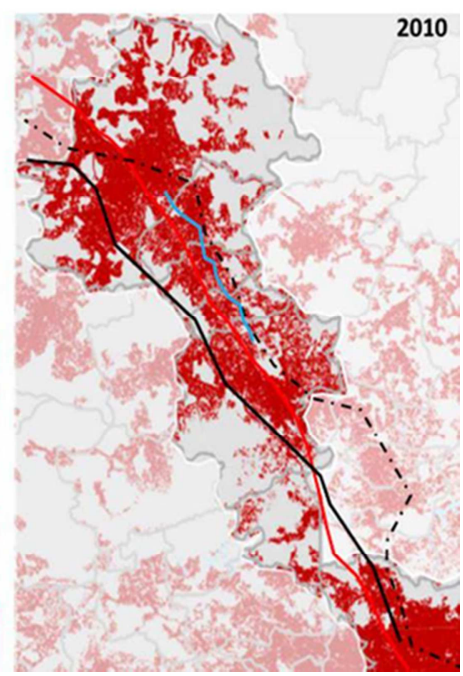

Source: Made from the image provided by LUME- Laboratório de urbanismo da metrópole

Figure 3. Urban Sprawl evolution on Northewest vector: From the scattery to the continuos territory.

\section{Conclusions}

From the new century, the evolution of the productive restructuring process have shaped new metropolitan territories which, in their sprawl are integrated, redefining concepts and set new limits. More advanced forms of urbanization in process of constitution, continuous, extensive, fragmented and overlapping, have more visible boundaries, but are complex from the point of view of their spatial relationships.

Work, consumption and leisure relationships, supported by recent technologies and modern infrastructure, tend to occur at expanded scales, but also integrating already consolidated tissues, producing more concentration than urban sprawl, or perhaps both simultaneously. Relations between sprawl and empty urban spaces are changed.

Therefore, changes in the relations between porosity and sprawl, alert to a new contemporary modes of life and production, which can mean a new cycle of the capitalist economy, which produces new morphological configurations and extended metropolitan scales.

From the 21 st century we can still talk about urban sprawl as a spatial result arising from the process of capitalist evolution or the urban sprawl dynamic is a stage of a broader process that has led to other forms more advanced of urbanization.

However this process of contemporary reterritorialization requires a new look able of understanding the totality of relationships that new metropolitan arrangements establish in the territory, from the local and the regional point of view.

\section{References}

[1] Castells, Manuel (1996). The Rise of the Network Society, The Information Age: Economy, Society and Culture Vol. I. Malden, MA; Oxford, UK: Blackw.

[2] Borja, Jordi; Castells, M. (1998). "The Local \& the Global: management of cities in the information age". Londres, Earthscan.

[3] BRENNER, Neil (2013). Implosions/Explosions: Towards a Study of Planetary Urbanization. Berlin: Jovis, 428-459.

[4] Eigenheer, Daniela (2018). "Vetor Noroeste Eixo São Paulo Campinas: Novos Territórios Metropolitanos". So Paulo. Doctoral Thesis. University of Sao Paulo FAU-USP.

[5] Eigenheer, Daniela (2011). "Tecnologia, Mobilidade e Dispersão Metropolitana: Sistema Anhanguera 
/Bandeirantes". Sao Paulo, Masters University Mackenzie

[6] Harvey, David. ( 2011). "The enigma of capital: and the crises of capitalism" Profile Books: London.

[7] Indovina, Francesco (2004). "La ciudad difusa. In: Lo urbano: en 20 autores contemporáneos". Ángel Martin Ramos.

[8] Reis, Nestor Goulart. (2006). "Notas sobre urbanização Dispersa e nova formas de tecido urbano". São Paulo: Via das Artes.

[9] Schiffer, Sueli (2004). "Globalização e Estrutura Urbana". Sao Paulo: Hucitec/FAPESP.
[10] Secchi, Bernardo. (2006 La città del XX secolo (The Twentieth Century City). Bari: Laterza.

[11] Soja, Edward (2013). Para além de postmetrolis. UFMG Magazine, $n^{\circ} 20$, pg.137-167.

[12] Viganò, Paola. (2016). Territories of Urbanism The Project as Knowledge Producer. EPFL Press. 